Article

\title{
Towards the Properties of Different Biomass-Derived Proteins via Various Extraction Methods
}

\author{
Lin Du*, Pablo J. Arauzo, Maria Fernanda Meza Zavala, Zebin Cao, Maciej Pawel Olszewski \\ and Andrea Kruse $\mathbb{D}$
}

Department of Conversion Technologies of Biobased Resources, Institute of Agricultural Engineering, University of Hohenheim, Garbenstrasse 9, 70599 Stuttgart, Germany; PabloJ.Arauzo@uni-hohenheim.de (P.J.A.); mezazava@gmail.com (M.F.M.Z.); zebin.cao@uni-hohenheim.de (Z.C.);

Maciej.Olszewski@uni-hohenheim.de (M.P.O.); Andrea_Kruse@uni-hohenheim.de (A.K.)

* Correspondence: du.lin@uni-hohenheim.de; Tel.: +49-(0)711-459-24707

Academic Editor: Rafael Luque Luís Adriano Santos Do Nascimento

Received: 30 December 2019; Accepted: 21 January 2020; Published: 23 January 2020

check for updates

\begin{abstract}
This study selected three representative protein-rich biomass-brewer's spent grain (BSG), pasture grass (PG), and cyanobacteria (Arthrospira platensis; AP) for protein extraction with different extraction methods (alkaline treatment, aqueous extraction, and subcritical water extraction). The yield, purity, molecular weight, oil-water interfacial tension, and thermal stability of the obtained proteins derived from different biomass and extraction methods were comprehensively characterized and compared. In the view of protein yield and purity, alkaline treatment was found optimal for BSG (21.4 and $60.2 \mathrm{wt} . \%$, respectively) and AP (55.5 and $68.8 \mathrm{wt.} \%$, respectively). With the decreased oil-water interfacial tension, the proteins from all biomass showed the potential to be emulsifier. BSG and AP protein obtained with chemical treatment presented excellent thermal stability. As a novel method, subcritical water extraction is promising in recovering protein from all three biomass with the comparable yield and purity as alkaline treatment. Furthermore, the hydrolyzed protein with lower molecular weight by subcritical water could promote its functions of foaming and emulsifying.
\end{abstract}

Keywords: lignocellulosic biomass; protein extraction; subcritical water extraction; protein characterization

\section{Introduction}

According to the United Nations, the world's population is expected to increase to 9.7 billion in 2050, and this requires a $70 \%$ increase in food production [1]. It is, therefore urgent to explore alternative methods of sustainable food processing to ensure food security with less environmental impact [2]. Moreover, the current consumption tends to be more plant-based food products rather than animal-based [3]. This led to more intensive utilization of biomass from different sources like agricultural side streams, waste material, and industrial by-products in the food sector $[4,5]$. Protein is a particularly essential nutrient for human development and health, and rich-protein foods have the potential to decrease worldwide malnutrition [6,7]. In this context, developing sustainable protein refinery techniques from various biomass are required to meet the increase of global protein demand [8].

The high productivity, low cost, and the variety of sources are essential advantages for the food industry acting as structural elements and techno-functional ingredients [9]. Beyond direct consumption for nutritional purposes, proteins are widely used as important ingredients in the food industry [10]. Proteins are macromolecular biopolymers, consisting of amino acid building blocks, and the structure of these building blocks determines protein properties. The properties of the protein that influence its functions in food systems include size, shape, net charge, polarity, structure, composition, and changes with chemical environments. The functionalities of proteins are determined by their structure [11]. For example, the hydrolyzed protein fractions with the increased number of free amino 
acids and carboxyl groups possess enhanced solubility, digestibility, and technofunctionality [10,12]. The amphiphilic attribute of protein can reduce the surface interfacial tension, which makes them utilized as emulsion and foaming agents $[13,14]$. Proteins are always obtained in the form of hydrolysate, with the reduced molecular size of protein contributing to the abovementioned functions. In this study, three significant properties (surface tension, molecular size, and thermal stability) are investigated on the extracted proteins.

Lignocellulosic biomass requires pretreatments to release its protein fraction because its recalcitrance depends on its complex composition and factors such as the degree of cellulose polymerization, lignin content, hemicellulose covering, porosity, and fiber strength [15]. Moreover, plant proteins always demonstrate various physical and chemical properties. Taking grass, for instance, the high-lignocellulosic content and cellulosic structure in grass reduce protein extraction yield [10]. The presence of both hydrophilic and lipophilic proteins in grass results in variable protein solubilities in water. The cellulose structure should be disrupted before extraction, and solvent or heating treatment is unavoidable during the extraction. Thus, grass protein is conventionally obtained by pressing or shearing to remove fibers, followed by a heat coagulation process that occurs at high temperatures [16]. Brewer's spent grain (BSG) known as the residue biomass in the brewing industry and usually contains 10-26 wt.\% of protein. The valorization of this industrial by-product can be realized by protein extraction and further conversion $[17,18]$. Attributing to the disrupted lignocellulosic structure during the beer production, BSG protein is more accessible during extraction. In the last decade, microalgae have been used to produce biofuel and intensively investigated as a new source of functional and nutritious compounds, such as lipid, pigment, and protein. Microalgae contain 40-60 wt.\% of protein, which is comparable to that of conventional food protein sources. However, these proteins cannot be digested in full extent, because a complete cell and protein extractability is usually limited by the rigid cell wall $[2,19,20]$. Furthermore, the types of proteins and their amino acids composition influence the protein accessibility during extraction. Glutelin found as a major protein in BSG, has a high solubility in alkaline solution [21]. A previous study found that the distribution of amino acids indicates protein solubility; non-essential amino acids tend to be more insoluble [22]. BSG contains the highest non-essential amino acids content among the studied feedstock materials (Table S1). Leafy protein Rubisco is usually obtained at $\mathrm{pH}$ lower than 10 [23]. The neutral or alkaline condition is not preferred for its recovery. However, the isoelectric point of over $50 \%$ plant protein is in the acidic range, and the proteins demonstrate high solubility at alkaline condition. It is, therefore, of great importance to select suitable extraction methods, according to different protein characteristics.

The high productivity, low cost, and wide variety are important advantages for biomass acting as protein feedstock [9]. The primary challenge of protein extraction from waste material or industrial by-products is to avoid denaturing or affecting their functional properties [24]. Pretreatment methods are broadly classified into biological, physical, chemical, and combinatorial [15,25]. All methods have advantages and disadvantages, while gentle treatments may not release all protein from the cell obtaining highly viscous extracts; harsh treatments can reduce viscosity but may result in the inactivation of labile proteins [26]. An effective pretreatment method should be simple, cost-effective, and most importantly, it should safeguard the fraction of interest by avoiding considerable losses [25]. Alkaline treatment is the most common method applied to agricultural and food residues for protein extraction. Through disulfide cross-linking breakage, the extractability of the protein is enhanced. It consists of the disruption of cell walls to extract protein easier and this extractability is influenced by certain extraction conditions such as biomass type, $\mathrm{pH}$, temperature, and extraction time $[10,27,28]$. Subcritical water treatment is emerging as a "green" extraction method avoiding the introduction of chemicals. With a decreased density and dielectric constant at subcritical conditions, water becomes a better solvent for protein. The increased ion concentration provides biomass the environment of hydrolyzing without the introduction of acid [29-31]. However, proteins are reported denatured in some studies due to high extraction temperature and pressure. 
From the aspect of valorization of waste biomass and sustainable refinery, the present study aimed to reveal the optimal protein extraction method for biomasses with different compositions. Brewer's spent grain (BSG), pasture grass (PG), and the cyanobacteria Arthrospira platensis (AP) were selected as a representative of lignocellulosic biomass with varied composition. As a comparison to aqueous extraction, alkaline treatment and subcritical water extraction were applied. The properties (molecular weight, oil-water interfacial tension, and thermal stability) that can affect functionality were investigated on the obtained protein concentrates.

\section{Results and Discussion}

\subsection{Extraction Method Comparison}

In this study, protein extraction yield involved two aspects, protein extraction into the aqueous phase and precipitation. The latter was performed identically for each biomass. The extraction parameters are critical for high quality and cost-effective protein production. Alkaline treatment and aqueous extraction are relatively mild, considering extraction temperature $\left(40{ }^{\circ} \mathrm{C}\right)$. However, introducing alkaline solution will increase production cost, and the extraction yield depends mainly on the volume of alkaline solution [32-34]. Subcritical water extraction is regarded as a 'green' method with shorter extraction duration (20 $\mathrm{min}$ in this study) [29,35]. However, the harsh reaction condition (200 ${ }^{\circ} \mathrm{C}, 40$ bar) may cause protein degradation and denaturation [36]. The effects of extraction parameters on the protein properties will be discussed in the following.

Aqueous extraction acted as a reference in this study, as well. It could be concluded that with chemical (alkaline treatment) and hydrothermal (subcritical water extraction) treatment, the protein extracted yields of all three biomass were improved. During aqueous extraction, the osmosis-caused diffusion in water through cell or cellulose structure was not strong enough for protein molecule permeation [37]. Strong alkaline conditions can partly remove the cellulosic structures with soluble protein dissolving in water $[27,28,38]$. Alkaline treatment showed the highest protein extraction yield for BSG (21.4 wt.\%) and AP (55.5 wt.\%), which is comparable with previous studies [39,40].

For PG, however, large shares of leaf proteins are located in the plasma membrane or cytoplasm. The mechanical pressing is always applied to fresh grass biomass to squeeze the protein-rich green juice in grass biorefinery [16,41]. Therefore, a combination of the cellulosic matrix disruption and mechanical fragmentation is necessary to promote the grass protein recovery. Subcritical water treatment increased by more than $5 \%$ of protein extraction yield comparing with alkaline treatment. It resulted from cellulose hydrolysis and cell wall disruption in subcritical water [42]. Nevertheless, the yield (6.7 wt.\%) was far less than the previous study on protein extraction from tea leaves, with the yield 95 wt. $\%$ at $95^{\circ} \mathrm{C}$ during $4 \mathrm{~h}$ extraction [34]. Extraction time was found crucial factor for an increased extraction yield [43].

The protein precipitation yield is highly interfered by the separation method. Many reported that the TCA precipitation reduces the solubility of concentrated protein [44]. Moreover, TCA is ineffective in precipitating unstructured or disordered protein that composes $30 \%$ of eukaryotic and $4.2 \%$ of eubacterial protein [45]. Thus, TCA precipitation is a preferred method for AP protein separation after alkaline treatment with a total extraction yield of $55.5 \mathrm{wt} \%$. After treated with subcritical water, the hydrolyzed protein/peptides fractions were not efficiently recovered with an overall yield of 19.9 wt.\%. Nevertheless, by removing salts and proteases, the high protein purity can be obtained by TCA precipitation. It is regarded as the most efficient protein separation method regardless of protein source [46-48].

\subsection{Protein Extraction Yield and Purity}

Neither the protein extraction yield nor the protein concentrate purity can solely indicate the protein recovery yield. The integration of both aspects was shown in Figure 1. Alkaline treatment followed by TCA precipitation is the optimized method for protein recovery from AP and BSG. 
Meanwhile, subcritical water treatment is more suitable for PG protein. It should be noted that although subcritical water treatment of AP and BSG showed lower purity than aqueous extraction, the yields were much higher. The lower purity resulted from carbohydrates contamination that was extracted during subcritical treatment. Other water-soluble substances such as sugars and salts were found extracted during the alkaline treatment [43]. Although TCA precipitation is the most promising method to separate protein, the contamination of polysaccharides and DNA is not avoidable [49]. All in all, given recovery yield, alkaline treatment, and subcritical water extraction were preferable for the three biomass. To conclude the ideal protein recovery method for specific biomass, a comprehensive economic analysis regarding capital and energy input, environmental consideration, as well as the protein quality and the market price is needed [33].

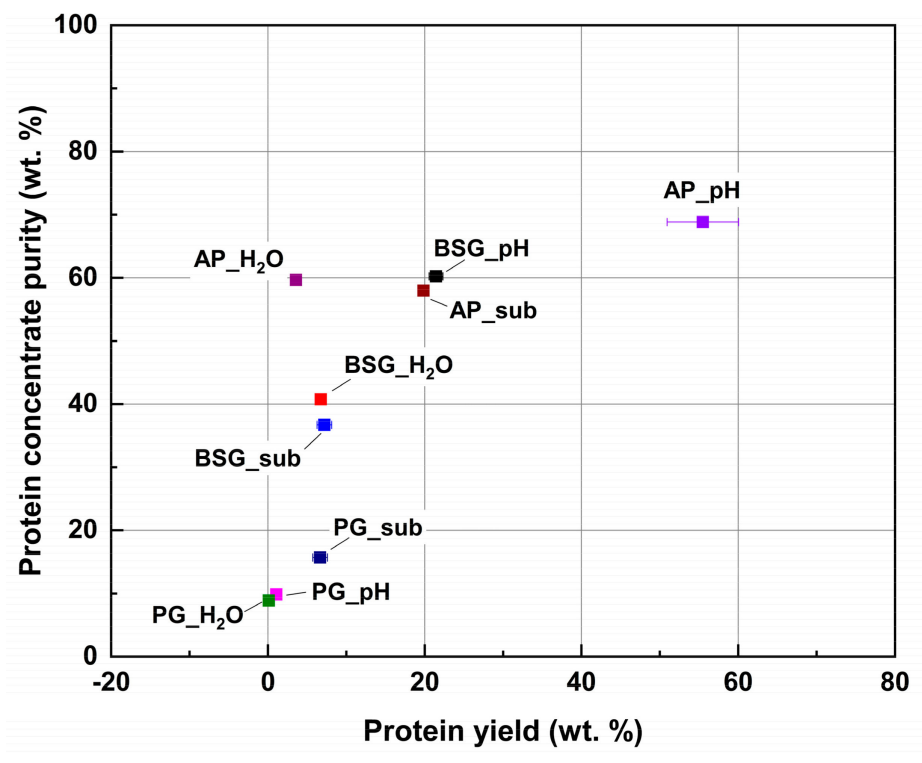

Figure 1. Graphical integration of protein extraction yield and protein concentrate purity.

The studied extraction methods accord to the concept of green chemistry that hazardous substances were neither used nor generated [50]. With subcritical water treatment, chemicals are completely avoided, and the extraction time was shortened by over $83 \%$ (Table 1). Additionally, the application of a continuous process can reduce energy input compared with batch extraction [51].

Table 1. A comparison between three extraction methods conditions and the obtained protein yield and purity.

\begin{tabular}{ccccc}
\hline & Alkaline & $\begin{array}{c}\text { Aqueous } \\
\text { Treatment }\end{array}$ & $\begin{array}{c}\text { Subcritical Water } \\
\text { Extraction }\end{array}$ & Extraction \\
\hline $\begin{array}{c}\text { Extraction time/duration } \\
\text { (min.) }\end{array}$ & 120 & 120 & 20 \\
$\begin{array}{c}\text { Temperature }\left({ }^{\circ} \mathrm{C}\right) \\
\text { pH }\end{array}$ & & 40 & 40 & 200 \\
Solvent involved & 11 & 7 & 7 \\
Protein yield & BSG & $21.4(0.9)$ & $6.8(0.1)$ & $7.2(0.9)$ \\
(wt.\%) & PG & $1.1(0.1)$ & $0.1^{\mathrm{a}}$ & $6.7(0.9)$ \\
& $\mathrm{AP}$ & $55.5(4.6)$ & $3.6(0.1)$ & $19.9(0.4)$ \\
Protein concentrate purity & $\mathrm{BSG}$ & $60.2(0.7)$ & $40.7(0.3)$ & $36.7(0.1)$ \\
(wt.\%) & PG & $9.8^{\mathrm{a}}$ & $8.9(0.3)$ & $15.7^{\mathrm{a}}$ \\
& $\mathrm{AP}$ & $68.8(0.2)$ & $59.7(0.1)$ & $58.0(0.3)$ \\
\hline
\end{tabular}

Values are expressed as mean $(n=3)$. In parentheses: standard deviation. ${ }^{\text {a }}$ Standard deviation is less than 0.05. 
In the conclusion, one possible integration of protein extraction from biomass in industrial applications is introduced, with alkaline and subcritical water treatment. Although alkaline treatment led to high protein extraction yield, unextracted protein remained in the residue. The previous study showed that the protein residue of BSG, after alkaline treatment, contains 3.63\% of N [28]. Further subcritical water treatment might further destroy the lignocellulosic structure of the residues, resulting in a promoted protein extraction efficiency. The combination of the two "green" extraction methods is a potential optimization approach in industrial protein biorefinery.

Nevertheless, further investigation should focus on the extraction mechanism of protein from the alkaline lignin cellulose residue under the subcritical condition. In the context of sustainability, the by-products can be applied and reused to reduce the waste. For example, the lignocellulose-rich solid residue might be used for animal feeding, energy-rich material production, and fermentation of ethanol. The aqueous waste that is rich in organic content, has the potential for biogas production.

\subsection{Molecular Weight}

The hydrolyzed protein fractions with lower molecular weight are preferred in the food industry because of improved nutritional quality and functional properties. The properties include solubility, digestibility, viscosity, emulsification, and gelation [52]. The molecular weights of obtained protein concentrate from three biomasses with different pretreatment methods varied (Figure 2). BSG_pH and $\mathrm{AP} \_\mathrm{H}_{2} \mathrm{O}$ covered the full range of molecular weights that were marked. As was discussed in the previous study, the BSG protein concentrates recovered with $\mathrm{pH}$ shifting method is promising as functioning agents in the food industry [28]. The BSG protein fractions of molecular weights between 14.5 and $50 \mathrm{KD}$ perform better given emulsifying and foaming [39,53].

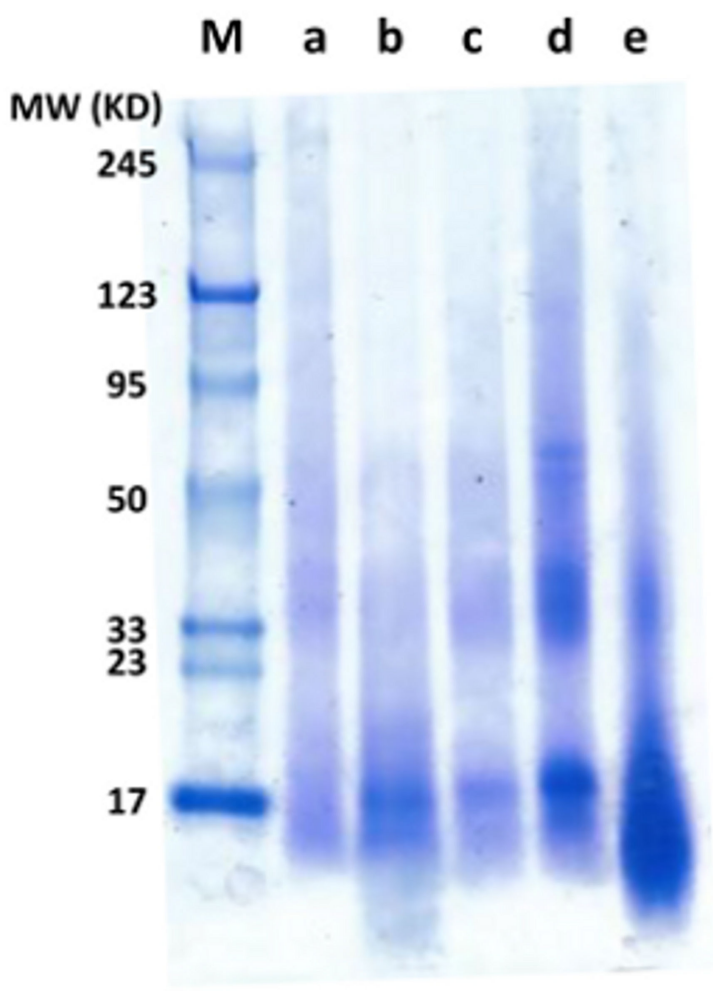

Figure 2. The molecular weight distribution of protein concentrates (protein concentration $0.5 w / w \%$ ). M: marker; a: BSG_pH; b: PG_pH; c: AP_pH; d: AP_H ${ }_{2} \mathrm{O}$; e: AP_sub.

The molecular weight of PG_pH and AP_pH mainly located in the range lower than 50 KD. During alkaline treatment, the solubility of protein was improved as a result of the disruption of the 
disulfide crosslink. Meanwhile, peptides fractions were generated. Besides, increased temperature and $\mathrm{pH}$ can cause protein denaturation and hydrolysis [10]. The structure unfolding was also observed on the $\mathrm{AP} \_\mathrm{pH}$ protein when comparing with $\mathrm{AP} \_\mathrm{H}_{2} \mathrm{O}$.

The more intensive dye of AP_sub in the lower molecular weight zones revealed mainly protein hydrolysates existing in the extract. The previous study of the algal protein showed better emulsifying properties on the acidic hydrolysates, which had similar molecular weights distribution as in our study [12]. Meanwhile, the solubility of protein concentrate was enhanced via subcritical water treatment. Excellent foaming properties were found with protein concentrates after the severe extraction process $[54,55]$. Hence, subcritical water treatment provides a novel alternative for biomass protein extraction with promoted functionalities.

\subsection{Surface Tension}

To investigate the potential of obtained protein concentrates as an emulsifier, the oil-water intersurface tension $(\gamma)$ of five different protein concentrates were measured along dropping time (30 $\mathrm{min}$ ). Firstly, all the protein concentrates were able to decrease the interface tension. It generally indicated the presence of surface-active proteins in the extracted concentrates [56,57]. Figure 3 displayed the lowest final interfacial tension of AP protein concentrates obtained with subcritical water treatment. The decreased speed and decreased extent of interfacial tension were comparable with that of a small-molecular surfactant in the previous study [58]. The capacity and the rate of decreasing interfacial tension of AP_sub indicated its excellent potential as a food emulsifier. It should be noted that other compounds with a low molecular weight such as carbohydrates and lipids could stabilize emulsion on the oil-water intersurface [13,58]. These impurities that were observed in extracted protein contribute to emulsion stabilization as well.

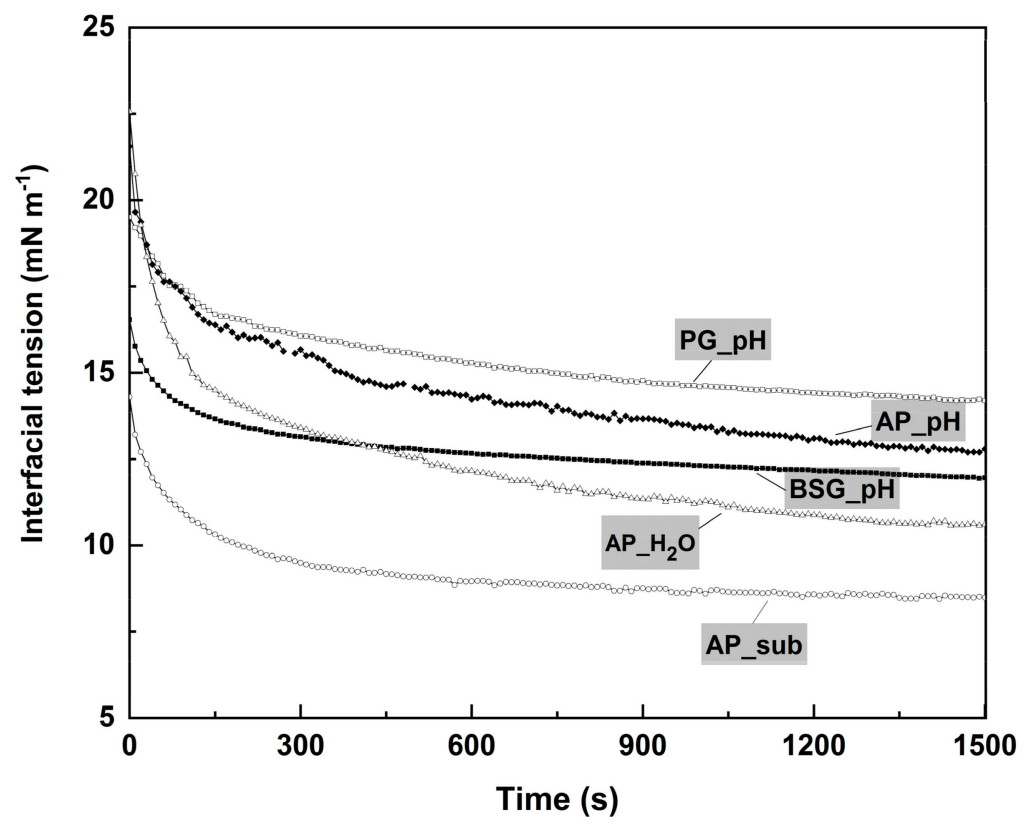

Figure 3. Oil-water interfacial tension profiles of protein concentrate (protein concentration $=0.1 \mathrm{wt}$. $\%$ ). Relative standard deviations are less than $5 \%(n=3)$.

\subsection{Thermal Stability}

This study exploited the thermogravimetric analysis (TGA) to explore the thermal behavior of the original feedstock and the extracted proteins by different methods. Graphs in Figure 4A indicated the variety of thermal behavior of different feedstock. Two peaks present in the derivative ther mogravimetric (DTG) curves of BSG and AP, while PG shows only one major peak. The peak in 
the range of $250-300{ }^{\circ} \mathrm{C}$ is associated with hemicellulose decomposition. Hemicellulose is mainly composed of carbohydrates [59]. BSG contains more hemicellulose [60] than AP and PG as the remaining carbohydrates from brewing. The second peak ranges from 300 to $400{ }^{\circ} \mathrm{C}$, which was presented in all three feedstocks, was related to the cellulose decomposition. It can be found that PG is mainly composed of cellulose because the leafy tissues are composed of three lamellas parts with cellulose inside [61]. The less stability of AP can be explained by the high content of protein, which reacts with carbohydrates via Maillard reaction pathways at $150{ }^{\circ} \mathrm{C}$ [62] and decompose to amino acids at a lower temperature.
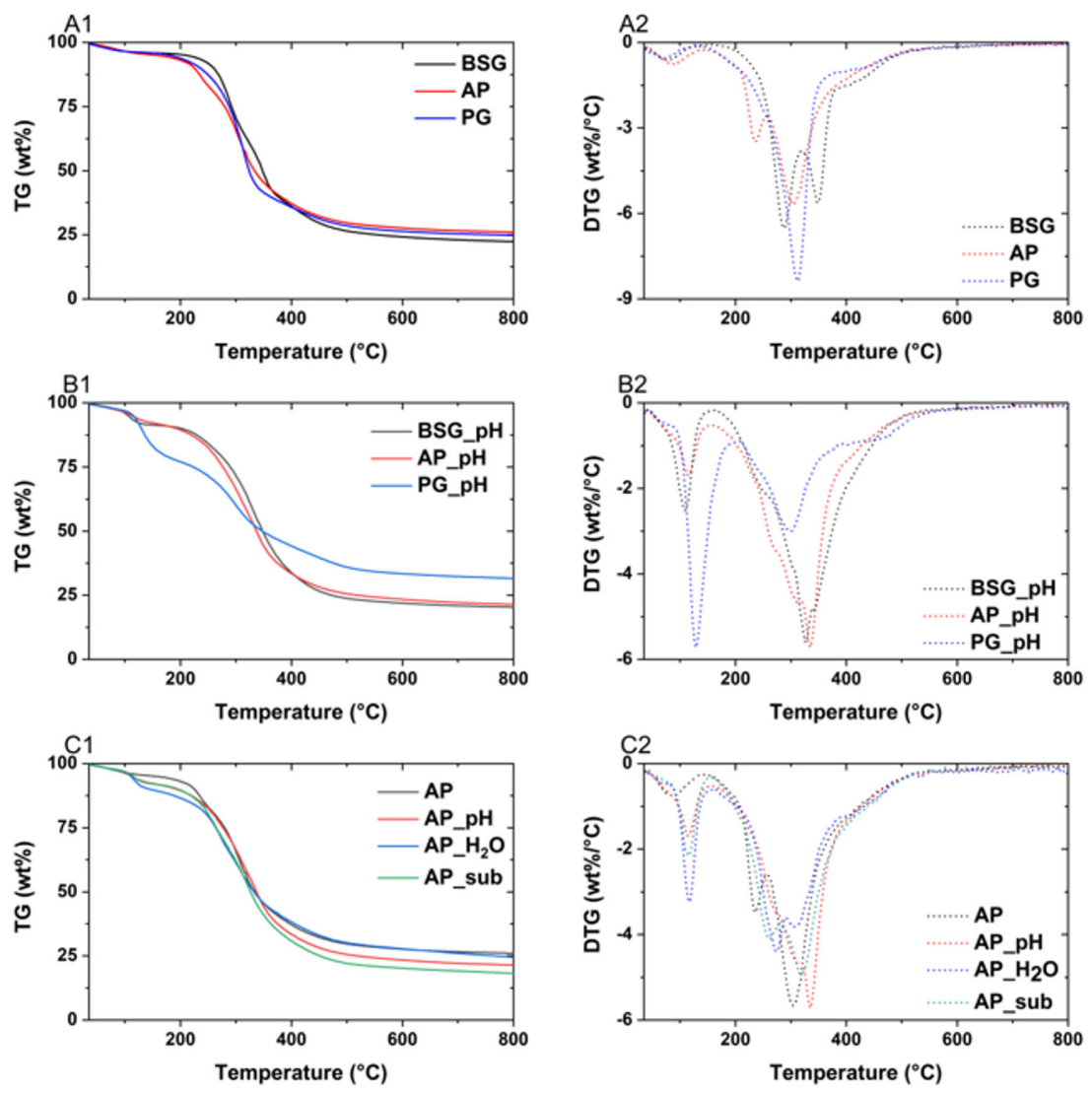

Figure 4. Comparison among TGA of original feedstock (A), proteins isolated from different feedstock by alkaline treatment (B), and Arthrospira platensis (AP) protein extracted by different treatments (C).

The thermal behavior of the extracted proteins is shown in Figure 4B,C. Figure 4B compared the proteins from different feedstock by alkaline treatment, while Figure $4 \mathrm{C}$ focuses on AP proteins isolated via various treatments. The first peak observed at the temperature range between 100 and $150{ }^{\circ} \mathrm{C}$ was assigned to dehydration. The PG isolated protein (alkaline treatment) was most hydrophilic, followed by BSG and AP (Figure 4B2). Figure 4C shows that AP lost the least mass during this temperature range, which further proved the hydrophilicity of the isolated proteins. In terms of the proteins, the hydrophilicity trend was $\mathrm{AP} \_\mathrm{H}_{2} \mathrm{O}>\mathrm{AP} \_$sub $>\mathrm{AP} \_\mathrm{pH}$. The second peak was observed at the temperature range between 250 and $350{ }^{\circ} \mathrm{C}$ and it was associated with the start of thermal decomposition of protein (volatilization of the proteins). A positive correlation between the purity of the isolated protein and the thermal stability was found by Ricci et al. (2018), and this is clearly indicated in Figure 4B2. AP_pH, with the highest purity, had the highest peak temperature. On the contrary, the peak temperature (second step) of PG_pH was $20{ }^{\circ} \mathrm{C}$ less than that of AP-pH due to the lowest purity. Due to the similar purity, AP_pH and BSG_pH had the almost same peak temperature. In Figure 4C2, even the purities of $\mathrm{AP}_{-} \mathrm{H}_{2} \mathrm{O}$ and $\mathrm{AP} \_$sub are almost the same; the peak temperature of $\mathrm{AP}_{-} \mathrm{H}_{2} \mathrm{O}$ was much lower than that of $\mathrm{AP} \_$sub. It might be that the isolated protein by aqueous 
treatment contained a high amount of impurities, which resulted in the instability of the $\mathrm{AP}_{-} \mathrm{H}_{2} \mathrm{O}$ protein. Other minor peaks presented in the DTG curves are the degradation of the non-protein substances [63].

It can be concluded that alkaline treatment is only suitable for extracting proteins from BSG and AP due to the high purity and thermal stability. The subcritical water extraction is also a promising method to obtain proteins from AP due to the relatively high thermal stability, and fewer chemicals are needed for this method.

\section{Materials and Methods}

\subsection{Materials}

Brewer's spent grain (BSG): the brewer's spent grains with a moisture content of $78 \mathrm{wt} . \%$ were obtained from the Hoepfner Brewery factory (Karlsruhe, Germany). It was stored at $-15^{\circ} \mathrm{C}$ until processed, to avoid the microbiological activity that takes place.

Pasture grass (PG): the pasture grass was obtained freshly from a farm in Münzesheim Kraichtal (Karlsruhe, Germany), and cut into pieces with an average length of $2-3 \mathrm{~cm}$. It was stored at $-15^{\circ} \mathrm{C}$ for further treatment.

Arthrospira platensis (AP): Arthrospira platensis was obtained from IGV GmbH (Nuthetal Germany) in dried pellet form with a dry weight of $94.9 \mathrm{wt} . \%$. Before extraction, A. platensis pellets were milled with Cyromill (Retsch GmbH, Haan, Germany) at frequency $30 \mathrm{~s}^{-1}$ for $1 \mathrm{~min}$ to a homogenous fine powder.

The compositions of the studied feedstock materials are shown in Table 2.

Table 2. The composition of the three feedstock materials.

\begin{tabular}{cccc}
\hline Composition (wt.\%) $^{\text {Bo }}$ & BSG & PG & AP \\
\hline Protein $^{\mathrm{a}}$ & 21.9 & 9.14 & $55.9^{\mathrm{c}}$ \\
$\mathrm{C}$ & $50.9(0.3)$ & $44.8(0.1)$ & $45.2^{\mathrm{c}}$ \\
$\mathrm{H}$ & $7.0(0.1)$ & $6.3^{\mathrm{c}}$ & $6.9^{\mathrm{c}}$ \\
$\mathrm{N}$ & $4.3(0.2)$ & $1.8^{\mathrm{c}}$ & $9.4^{\mathrm{c}}$ \\
$\mathrm{S}$ & $0.2^{\mathrm{c}}$ & $0.1^{\mathrm{c}}$ & $0.6^{\mathrm{c}}$ \\
$\mathrm{O}^{\mathrm{b}}$ & $33.6^{\mathrm{c}}(0.4)$ & $40.1(0.1)$ & $32.4(0.1)$ \\
Ash & $3.9^{\mathrm{c}}$ & $7.0(0.1)$ & $5.5(0.1)$ \\
Dry Weight & $2^{\mathrm{c}}$ & $29.7(0.8)$ & $94.9(0.2)$ \\
\hline
\end{tabular}

Values are expressed as mean $(n=3)$. In parentheses: standard deviation. ${ }^{\text {a }}$ Protein content based on the amino acids composition $(n=1) ;{ }^{\mathrm{b}} \mathrm{O}$ content calculated according to elementary and ash composition; ${ }^{\mathrm{c}}$ Standard deviation is less than 0.05 .

\subsection{Protein Concentrates Preparation}

\subsubsection{Alkaline Treatment}

BSG, PG, and AP were suspended in $0.1 \mathrm{M} \mathrm{NaOH}$ and distilled $\mathrm{H}_{2} \mathrm{O}$ to reach a $\mathrm{pH}>11$ with a final solid to liquid ratio of 1:10 $(w / w)$. The mixture was stirred for $2 \mathrm{~h}$ at $40{ }^{\circ} \mathrm{C}$ and then centrifuged at $13,500 \times \mathrm{g}, 4^{\circ} \mathrm{C}$ for $20 \mathrm{~min}$ (Z $326 \mathrm{~K}$, HERMLE Labortechnik GmbH, Wehingen, Germany). The protein-rich supernatant was taken for precipitation and further analysis.

\subsubsection{Aqueous Extraction}

The same amount of feedstock BSG, PG, and AP were mixed with distilled water (solid to liquid ratio 1:10 $w / w)$. Extraction took place at $40{ }^{\circ} \mathrm{C}$ for $2 \mathrm{~h}$ and the same separation method as for alkaline treatment was applied. 


\subsubsection{Subcritical Water Extraction}

Subcritical water extraction was performed in a semi-continuous reactor at the condition: temperature $200{ }^{\circ} \mathrm{C}$, pressure $40 \mathrm{bar}$, and flowrate $6 \mathrm{~mL} / \mathrm{min}$. After $20 \mathrm{~min}$. extraction duration, corresponding aqueous extracts were obtained and kept for precipitation and analysis.

\subsubsection{Trichloroacetic Acid (TCA) Precipitation}

The protein-rich aqueous extracts were adjusted to $\mathrm{pH} 3.0$ with $1.0 \mathrm{M}$ trichloroacetic acid (TCA). This $\mathrm{pH}$ was reported as the isoelectric points of most plant proteins, at which the interaction between protein molecules and water is minimized, resulting in low solubility [27]. Subsequently, the insoluble protein precipitated and recovered after centrifugation at $13,500 \times g, 4^{\circ} \mathrm{C}$ for $20 \mathrm{~min}$. The obtained pellets were frozen at $-15^{\circ} \mathrm{C}$ until they were lyophilized in a freeze dryer (ALPHA 1-2LD plus from CHRIST GmbH, Osterode am Harz, Germany).

The freeze-dried extracts are denoted respectively as BSG_pH, PG_pH, and AP_pH (from alkaline treatment), BSG_H $\mathrm{H}_{2} \mathrm{O}, \mathrm{PG}_{-} \mathrm{H}_{2} \mathrm{O}$, and AP_H2O (from aqueous extraction), and BSG_sub, PG_sub, and AP_sub (from subcritical water extraction). Figure 5 demonstrates the experimental process and the appearances of the extracted proteins.

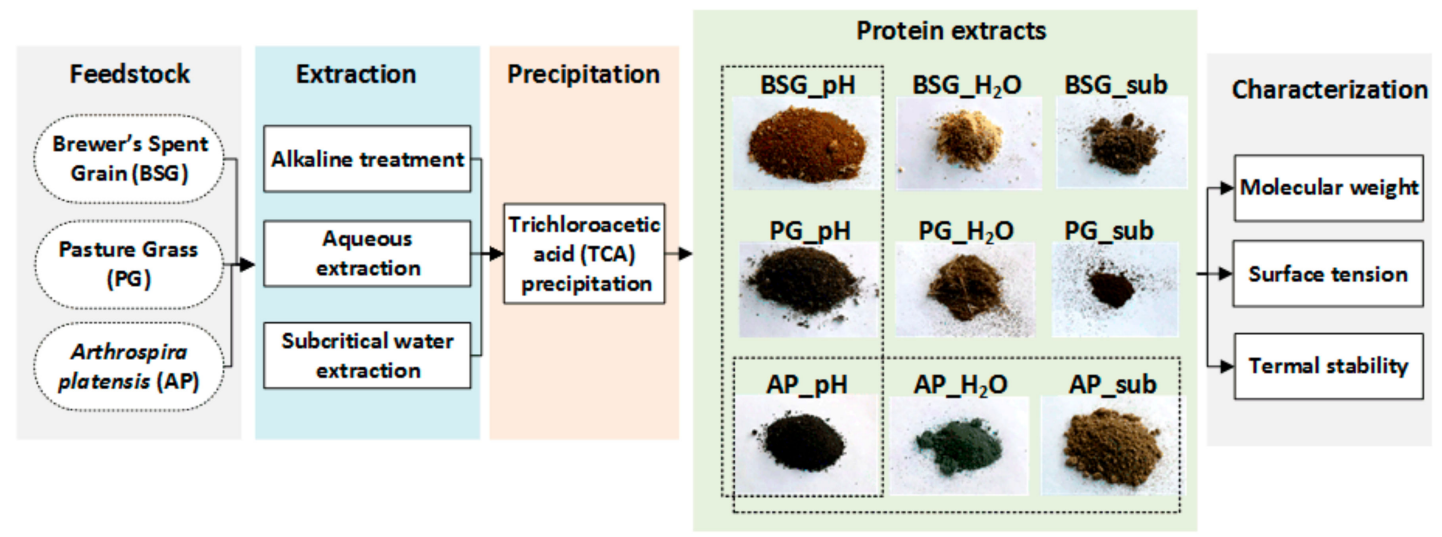

Figure 5. Scheme of the experimental process for protein extraction by three different methods (alkaline treatment, aqueous extraction, and subcritical water extraction) of three types of biomass (brewer's spent grains (BSG), pasture grass (PG), and Arthrospira platensis (AP)).

\subsection{Composition Analysis}

The elemental analysis was carried out in an Elemental Analyzer EA3000 Series (EuroVector Instruments \& Software Srl, Pavia, Italy) equipped with a thermal conductivity detector (TCD) to determine the percentage composition of CHNS (carbon, hydrogen, nitrogen, and sulfur). Proximate analysis was performed according to the standard test method ASTM D1762-84 (2013) to determine moisture content and ash content in solid samples. The elemental analysis was applied to all the feedstock materials and protein isolates, and a proximate analysis was applied only to the feedstock.

Concerning the low amounts of protein extracts obtained, it is challenging to perform Kjeldahl protein or amino acid analysis. The protein content of the extracts was estimated with the total nitrogen content, and the nitrogen to protein factor 6.25 [64] (Equation (1)).

$$
\text { Protein content }(\text { wt. } \%)=\text { Nitrogen }(\text { wt. } \%) \times 6.25 \text {. }
$$

\subsection{Lowry Protein Determination}

The protein in aqueous extracts was treated with copper (II) salt under alkaline conditions and then reacted with Folin and Ciocalteu's phenol reagent, which generated absorption at $750 \mathrm{~nm}$ (Gerhardt 1994; Lowry et al., 1951). The concentrations of protein in the extracts were determined according to the 
standard. Reagents $\mathrm{A}\left(2.0 \% \mathrm{Na}_{2} \mathrm{CO}_{3}+0.1 \mathrm{~N} \mathrm{NaOH}\right), \mathrm{B}\left(0.5 \% \mathrm{CuSO}_{4}\right.$ with $\left.1 \% \mathrm{C}_{4} \mathrm{H}_{4} \mathrm{NaO}_{6} 4 \mathrm{H}_{2} \mathrm{O}\right)$, and C (50 mL A + $1 \mathrm{~mL} \mathrm{~B}$ ) were prepared as in the previous study. Chemicals were purchased in analysis pure grade from Merck KGaA (Darmstadt, Germany) and VWR International GmbH (Darmstadt, Germany). Bovine serum albumin (purity $\geq 98.5 \%$, Merck KGaA) was used as a standard with concentration from 20 to $200 \mathrm{mg} / \mathrm{L}$. The test was performed in a 96-well microplate. Of the standard or sample mixed $40 \mu \mathrm{L}$ with $200 \mu \mathrm{L}$ of reagent $\mathrm{C}$ reacted for $10 \mathrm{~min}$. Then $20 \mu \mathrm{L}$ of the $1 \mathrm{~N}$ Folin and Ciocalteu's phenol reagent (VWR International $\mathrm{GmbH}$ ) was added and mixed well. The mixture solutions were kept in the dark for $60 \mathrm{~min}$ before the absorbance was read with $750 \mathrm{~nm}$ in an EPOCH2 plate reader (BioTek Instruments $\mathrm{GmbH}$, Bad Friedrichshall, Germany).

\subsection{Extraction Yield and Purity Determination}

The protein extraction yield and purity were determined based on Equations (2) and (3), respectively.

$$
\text { Protein extraction yield }(\mathrm{wt} . \%)=\frac{\text { Amount of dried protein precipitate }(\mathrm{mg})}{\text { Protein content in biomass }(\mathrm{mg})} \times 100 \%
$$

$$
\text { Protein purity }(\text { wt. } \%)=\frac{\text { Protein content in precipitate }(\mathrm{mg})}{\text { Protein preciAmount of dried protein precipitate }(\mathrm{mg})} \times 100 \% \text {. }
$$

\subsection{Protein Functional Properties Characterization}

Due to the higher protein recovery yield and research interest, the functionality characterization was performed on the extracts: $\mathrm{BSG}_{-} \mathrm{pH}, \mathrm{PG} \_\mathrm{pH}, \mathrm{AP} \_\mathrm{pH}, \mathrm{AP} \_\mathrm{H}_{2} \mathrm{O}$, and $\mathrm{AP} \_$sub.

\subsubsection{SDS-Polyacrylamide Gel Electrophoresis (SDS-PAGE)}

SDS-PAGE carried out on the protein extracts to observe the molecular weight with the Mini-protean II system (Bio-Rad Laboratories $\mathrm{GmbH}$, München, Germany). The solutions with protein concentrations of $0.5 \mathrm{wt}$ \% were prepared with distilled water for BSG_pH, PG_pH, AP_pH, AP_H and AP_sub. The suspensions were diluted with buffer solution containing 5\% 1 -mercaptoethanol (purity $\geq 98 \%$ ), $0.5 \mathrm{M}$ Tris- $\mathrm{HCl} \mathrm{pH} 6.8$ (purity $\geq 99.8 \%$ ), 25\% glycerol (purity $\geq 99 \%$ ), 10\% SDS, and $5 \%$ bromophenol blue indicator (Merck KGaA). Of each sample $10 \mu \mathrm{L}$ was loaded into each cell and followed by the electrophoresis at $200 \mathrm{~V}$ for $40 \mathrm{~min}$. The gel was stained with Coomassie brilliant blue R-250 (Bio-Rad Laboratories GmbH, München, Germany) for 2 h and washed with 15\% methanol and $10 \%$ acetic acid solution overnight. A pre-stained marker (Roti ${ }^{\circledR}$-Mark, Carl Roth $\mathrm{GmbH}+\mathrm{Co}$. KG, Karlsruhe, Germany) with a range from 17 to $245 \mathrm{kDa}$ was used to determine the molecular weight distribution.

\subsubsection{Interfacial Tension}

The interfacial tension was carried out on five protein extracts with a concentration of $0.1 \mathrm{wt} . \%$. A drop-shape analyzer (DSA-G10, MK2, Krüss, Charlotte, NC, U.S.A.) was used to analyze the interfacial tension at the oil-water interface. A drop of the sample was formed at the tip of the syringe, whose shape was calculated from the balance of force on the drop following the Young-Laplace equation. The interfacial tension was then determined from the shape of the drop. Sample solutions were firstly put in a syringe with a narrow tip $(\mathrm{d}=0.90 \mathrm{~mm})$ then into a cuvette filled with the oil phase (MCT, Miglyol 812, Cremer Oleo GmbH \& Co. KG, Hamburg, Germany). The cuvette was placed onto the optical bench where the light source can go through. The shape profile of the drop was recorded by a camera and processed by the software. The densities of samples were measured by a digital density meter (DMA 35N, Anton Paar Physica, Ostfildern- Scharnhausen, Germany). 


\subsubsection{Thermogravimetric Analysis}

The thermogravimetric analysis (Netzsch STA 449 F5, NETZSCH-Gerätebau GmbH, Selb, Germany) was conducted to analyze the thermal stability of the original feedstock and isolated proteins. The sample was loaded into an $\mathrm{Al}_{2} \mathrm{O}_{3}$ crucible and heated to $800{ }^{\circ} \mathrm{C}$ with a constant heating rate of $10^{\circ} \mathrm{C} / \mathrm{min}$ in the $\mathrm{N}_{2}$ atmosphere $(70 \mathrm{~mL} / \mathrm{min})$.

Extractions and analyses were implemented at least three times, and the relative standard deviation of each result was smaller than $10 \%$. The thermogravimetric analysis was conducted only once. The main error of the experiments came from biomass heterogeneity and temperature control.

\section{Conclusions}

The study demonstrated the protein recovery efficiency from various biomasses. Alkaline treatment is suitable for BSG and AP with a high protein yield and purity, while subcritical water extraction favorable for PG. The extracted protein demonstrated superior or comparable properties in comparison with original biomass and other common proteins. The hydrolyzed product from subcritical water extraction contributes to the emulsification function, which suggests it a promising sustainable extraction technique.

This can be used as the basis for a biorefinery. First an alkaline treatment is applied. This leads to a protein-rich extract and a lignocellulose-rich residue (Figure 6). This residue is extracted with hot liquid water (subcritical water). Here again a protein rich extract was generated, which is mixed with the extract produced by the first, alkaline extraction. From this mixture of aqueous liquids, solid protein is precipitated. This is the wished product. The aqueous solution, left after protein precipitation is delivered to a biogas plant. The solid lignocellulose-rich residue, twice extracted, is still reach in cellulose. It can be further processed, e.g., by splitting of cellulose to glucose and consecutive ethanol production (2nd generation bioethanol), or it can be pyrolyzed to get a solid fuel.

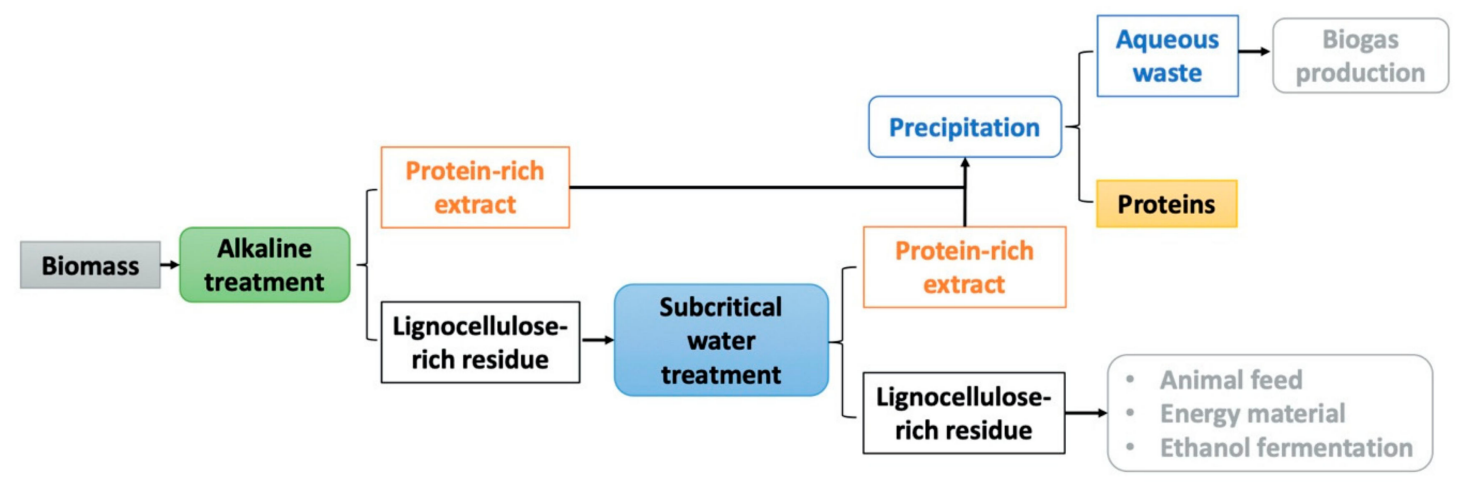

Figure 6. Integration of alkaline and subcritical water treatment to optimize protein extraction from biomass.

Such a double-extraction could be for example integrated in a large brewery, in this case BSG is the feedstock. Here, the extraction could be integrated in the steam-heating system and the solid residue may be used to produce the heat.

In the case of grass, it is interesting to produce proteins from grass directly, instead to use it as fodder for cattle production. The efficiency was higher and the greenhouse gas production was much lower. In this case it has to be investigated to use the solid lignocellulose-residue e.g., for paper production, because of the fiber-like structure.

Today, more and more people want to avoid protein from animals, because of different reasons. To produce proteins from plants will become more and more important and would be an interesting business case. 
Supplementary Materials: The following are available online. Table S1: The amino acids composition of the studied feedstock.

Author Contributions: L.D., P.J.A. and A.K. conceptualized the research. L.D., M.F.M.Z., Z.C. and M.P.O. outlined the methodology and performed the experiments. L.D. and P.J.A. analyzed and evaluated the data. L.D. visualized the results and prepared the original manuscript. A.K. and P.J.A. reviewed the manuscript. All the work was supervised by A.K. All authors have read and agreed to the published version of the manuscript.

Funding: This research was funded by China Scholarship Council (CSC) under the grant agreement No. 201508080008 and No.201508080044, the Bioeconomy Graduate Program of the State of Baden-Württemberg, Germany, BBW ForWerts (200045, Baden-Württemberg, Germany), and the European Union's Horizon 2020 research and innovation program under the Marie Skłodowska-Curie Grant Agreement No. 721991.

Acknowledgments: Thanks to Ms. Laixin Dai, and the department of Food Physics and Meat Science, Hohenheim, for their support with protein characterization.

Conflicts of Interest: The authors declare no conflict of interest.

\section{References}

1. Godfray, H.C.J.; Beddington, J.R.; Crute, I.R.; Haddad, L.; Lawrence, D.; Muir, J.F.; Pretty, J.; Robinson, S.; Thomas, S.M.; Toulmin, C. Food Security: The Challenge of Feeding 9 Billion People. Science 2010, 327, 812-818. [CrossRef]

2. Bleakley, S.; Hayes, M. Algal Proteins: Extraction, Application, and Challenges Concerning Production. Foods 2017, 6, 33. [CrossRef] [PubMed]

3. Baines, D.; Seal, R. Natural Food Additives, Ingredients and Flavourings, 1st ed.; Woodhead Publishing: Cambridge, UK, 2012.

4. Lammens, T.M.; Franssen, M.C.R.; Scott, E.L.; Sanders, J.P.M. Availability of protein-derived amino acids as feedstock for the production of bio-based chemicals. Biomass Bioenerg. 2012, 44, 168-181. [CrossRef]

5. Sari, Y.W. Biomass and its potential for protein and amino acids: Valorizing agricultural by-products. Ph.D. Thesis, Wageningen University, Wageningen, The Netherlands, January 2015.

6. Nadathur, S.R.; Wanasundara, J.P.D.; Scanlin, L. Sustainable Protein Source; Academic Press: Cambridge, MA, USA, 2016; ISBN 978-0-12-802778-3.

7. López, D.N.; Galante, M.; Robson, M.; Boeris, V.; Spelzini, D. Amaranth, quinoa and chia protein isolates: Physicochemical and structural properties. Int. J. Biol. Macromol. 2018, 109, 152-159. [CrossRef]

8. Aydemir, L.Y.; Yemenicioĝlu, A. Potential of Turkish Kabuli type chickpea and green and red lentil cultivars as source of soy and animal origin functional protein alternatives. LWT - Food Sci. Technol. 2013, 50, 686-694. [CrossRef]

9. Pham, T.T.; Tran, T.T.T.; Ton, N.M.N.; Le, V.V.M. Effects of pH and Salt Concentration on Functional Properties of Pumpkin Seed Protein Fractions. J. Food Process. Preserv. 2017, 41. [CrossRef]

10. Contreras, M.d.M.; Lama-Muñoz, A.; Manuel Gutiérrez-Pérez, J.; Espínola, F.; Moya, M.; Castro, E. Protein extraction from agri-food residues for integration in biorefinery: Potential techniques and current status. Bioresour. Technol. 2019, 280, 459-477. [CrossRef]

11. Hettiarachchy, N.S.; Sato, K.; Marshall, M.R.; Kannan, A. Food Proteins and Peptides: Chemistry, Functionality, Interactions, and Commercialization; CRC Press: Boca Raton, FL, USA, 2016; ISBN $9781138199002-C A T \#$ K31432.

12. Dai, L.; Bergfreund, J.; Reichert, C.L.; Fischer, P.; Weiss, J. Shear rheological properties of acid hydrolyzed insoluble proteins from Chlorella protothecoides at the oil-water interface. J. Colloid Interf. Sci. 2019, 551, 297-304. [CrossRef]

13. Romero, A.; Beaumal, V.; David-Briand, E.; Cordobés, F.; Anton, M.; Guerrero, A. Interfacial and emulsifying behaviour of crayfish protein isolate. LWT - Food Sci. Technol. 2011, 44, 1603-1610. [CrossRef]

14. Kinsella, J.E. Functional properties of proteins in foods: A survey. CRC Crit. Rev. Food Sci. Nutr. 1976, 7, 219-280. [CrossRef]

15. Agbor, V.B.; Cicek, N.; Sparling, R.; Berlin, A.; Levin, D.B. Biomass pretreatment: Fundamentals toward application. Biotechnol. Adv. 2011, 29, 675-685. [CrossRef] [PubMed]

16. Dotsenko, G.; Lange, L. Enzyme Enhanced Protein Recovery from Green Biomass Pulp. Waste Biomass Valori. 2017, 8, 1257-1264. [CrossRef]

17. Montusiewicz, A.; Pasieczna-Patkowska, S.; Lebiocka, M.; Szaja, A.; Szymańska-Chargot, M. Hydrodynamic cavitation of brewery spent grain diluted by wastewater. Chem. Eng. J. 2017, 313, 946-956. [CrossRef] 
18. Lynch, K.M.; Steffen, E.J.; Arendt, E.K. Brewers' spent grain: A review with an emphasis on food and health. J. Inst. Brew. 2016, 122, 553-568. [CrossRef]

19. Becker, E.W. Micro-algae as a source of protein. Biotechnol. Adv. 2007, 25, 207-210. [CrossRef] [PubMed]

20. Choi, Y.R.; Markakis, P. Blue-green algae as a source of protein. Food Chem. 1981, 7, 239-247. [CrossRef]

21. Celus, I.; Brijs, K.; Delcour, J.A. The effects of malting and mashing on barley protein extractability. J. Cereal Sci. 2006, 44, 203-211. [CrossRef]

22. Schingoethe, D.J.; Ahrar, M. Protein Solubility, Amino Acid Composition, and Biological Value of Regular and Heat-Treated Soybean and Sunflower Meals. J. Dairy Sci. 1979, 62, 925-931. [CrossRef]

23. Kinsella, J.E. Ribulose bisphosphate carboxylase/oxygenase (rubisco) from green leaves_Potential as a food protein. Food Rev. Int. 1988, 4, 93-127.

24. Kärenlampi, S.O.; White, P.J. Potato Proteins, Lipids, and Minerals. In Advances in Potato Chemistry and Technology; Academic Press: Cambridge, MA, USA, 2009; pp. 99-125.

25. Sindhu, R.; Binod, P.; Pandey, A. Biological pretreatment of lignocellulosic biomass - An overview. Bioresour. Technol. 2016, 199, 76-82. [CrossRef]

26. Voudouris, P.; Tenorio, A.T.; Lesschen, J.P.; Mulder, W.; Kyriakopoulou, K.E.; Sanders, J.P.M.; van der Goot, A.J.; Bruins, M.E. Sustainable protein technology: An. evaluation on the STW Protein programme and an outlook for the future; Wageningen Food \& Biobased Research: Wageningen, the Netherlands, 2017.

27. Cavonius, L.R.; Albers, E.; Undeland, I. pH-shift processing of Nannochloropsis oculata microalgal biomass to obtain a protein-enriched food or feed ingredient. Algal Res. 2015, 11, 95-102. [CrossRef]

28. Arauzo, P.J.; Du, L.; Olszewski, M.P.; Meza Zavala, M.F.; Alhnidi, M.J.; Kruse, A. Effect of protein during hydrothermal carbonization of brewer's spent grain. Bioresour. Technol. 2019, 293. [CrossRef] [PubMed]

29. Kruse, A.; Dahmen, N. Water-A magic solvent for biomass conversion. J. Supercrit. Fluids 2014, 96, 36-45. [CrossRef]

30. Alenezi, R.; Leeke, G.A.; Santos, R.C.D.; Khan, A.R. Hydrolysis kinetics of sunflower oil under subcritical water conditions. Chem. Eng. Res. Des. 2009, 87, 867-873. [CrossRef]

31. Clifford, T. Fundamentals of Supercritical Fluids; Oxford University Press: Oxford, UK, 1999; ISBN 9780198501374.

32. Kammes, K.L.; Bals, B.D.; Dale, B.E.; Allen, M.S. Grass leaf protein, a coproduct of cellulosic ethanol production, as a source of protein for livestock. Anim. Feed Sci. Technol. 2011, 164, 79-88. [CrossRef]

33. Bals, B.; Dale, B.E. Economic comparison of multiple techniques for recovering leaf protein in biomass processing. Biotechnol. Bioeng. 2011, 108, 530-537. [CrossRef]

34. Zhang, C.; Sanders, J.P.M.; Bruins, M.E. Critical parameters in cost-effective alkaline extraction for high protein yield from leaves. Biomass Bioenerg. 2014, 67, 466-472. [CrossRef]

35. Ahmed, R.; Chun, B.S. Subcritical water hydrolysis for the production of bioactive peptides from tuna skin collagen. J. Supercrit. Fluids 2018, 141, 88-96. [CrossRef]

36. Feyzi, S.; Milani, E.; Golimovahhed, Q.A. Grass Pea (Lathyrus sativus L.) Protein Isolate: The Effect of Extraction Optimization and Drying Methods on the Structure and Functional Properties. Food Hydrocoll. 2018, 74, 187-196. [CrossRef]

37. Safi, C.; Ursu, A.V.; Laroche, C.; Zebib, B.; Merah, O.; Pontalier, P.-Y.; Vaca-Garcia, C. Aqueous extraction of proteins from microalgae: Effect of different cell disruption methods. Algal Res. 2014, 3, 61-65. [CrossRef]

38. Zhao, X.; Stökle, K.; Becker, G.C.; Zimmermann, M.; Kruse, A. Hydrothermal carbonization of Spirulina platensis and Chlorella vulgaris combined with protein isolation and struvite production. Bioresour. Technol. Reports 2019, 6, 159-167. [CrossRef]

39. Celus, I.; Brijs, K.; Delcour, J.A. Enzymatic hydrolysis of Brewers' spent grain proteins and technofunctional properties of the resulting hydrolysates. J. Agric. Food Chem. 2007, 55, 8703-8710. [CrossRef] [PubMed]

40. Safi, C.; Charton, M.; Ursu, A.V.; Laroche, C.; Zebib, B.; Pontalier, P.Y.; Vaca-Garcia, C. Release of hydro-soluble microalgal proteins using mechanical and chemical treatments. Algal Res. 2014, 3. [CrossRef]

41. Pirie, N.W. Leaf Protein as a Human Food. Sci. New Ser. 1966, 152, 1701-1705. [CrossRef] [PubMed]

42. Sasaki, M.; Adschiri, T.; Arai, K. Kinetics of Cellulose Conversion at $25 \mathrm{MPa}$ in Sub- and Supercritical Water. AIChE J. 2004, 50, 192-202. [CrossRef]

43. Gerde, J.A.; Wang, T.; Yao, L.; Jung, S.; Johnson, L.A.; Lamsal, B. Optimizing protein isolation from defatted and non-defatted Nannochloropsis microalgae biomass. Algal Res. 2013, 2, 145-153. [CrossRef] 
44. Carpentier, S.C.; Witters, E.; Laukens, K.; Deckers, P.; Swennen, R.; Panis, B. Preparation of protein extracts from recalcitrant plant tissues: An evaluation of different methods for two-dimensional gel electrophoresis analysis. Proteomics 2005, 5, 2497-2507. [CrossRef]

45. Ward, J.J.; Sodhi, J.S.; McGuffin, L.J.; Buxton, B.F.; Jones, D.T. Prediction and Functional Analysis of Native Disorder in Proteins from the Three Kingdoms of Life. J. Mol. Biol. 2004, 337, 635-645. [CrossRef]

46. Nandakumar, M.P.; Shen, J.; Raman, B.; Marten, M.R. Solubilization of trichloroacetic acid (TCA) precipitated microbial proteins via $\mathrm{NaOH}$ for two-dimensional electrophoresis. J. Proteome Res. 2003, 2, 89-93. [CrossRef]

47. Fic, E.; Kedracka-Krok, S.; Jankowska, U.; Pirog, A.; Dziedzicka-Wasylewska, M. Comparison of protein precipitation methods for various rat brain structures prior to proteomic analysis. Electrophoresis 2010, 31, 3573-3579. [CrossRef]

48. Barbarino, E.; Lourenço, S.O. An evaluation of methods for extraction and quantification of protein from marine macro- and microalgae. J. Appl. Phycol. 2005, 17, 447-460. [CrossRef]

49. Oliveira, R.; Marques, F.; Azeredo, J. Purification of polysaccharides from a biofilm matrix by selective precipitation of proteins. Biotechnol. Tech. 1999, 13, 391-393. [CrossRef]

50. United States Environmental Protection Agency. Available online: https://www.epa.gov/greenchemistry/ basics-green-chemistry (accessed on 29 December 2019).

51. Vilkhu, K.; Mawson, R.; Simons, L.; Bates, D. Applications and opportunities for ultrasound assisted extraction in the food industry - A review. Innov. Food Sci. Emerg. Technol. 2008, 9, 161-169. [CrossRef]

52. Hou, Y.; Wu, Z.; Dai, Z.; Wang, G.; Wu, G. Protein hydrolysates in animal nutrition: Industrial production, bioactive peptides, and functional significance. J. Anim. Sci. Biotechnol. 2017, 8, 1-13. [CrossRef] [PubMed]

53. Wang, J.; Zhao, M.; Yang, X.; Jiang, Y. Improvement on functional properties of wheat gluten by enzymatic hydrolysis and ultrafiltration. J. Cereal Sci. 2006, 44, 93-100. [CrossRef]

54. Garcia, E.S.; Van Leeuwen, J.J.A.; Safi, C.; Sijtsma, L.; Van Den Broek, L.A.M.; Eppink, M.H.M.; Wijffels, R.H.; Van Den Berg, C. Techno-Functional Properties of Crude Extracts from the Green Microalga Tetraselmis suecica. J. Agric. Food Chem. 2018, 66, 7831-7838. [CrossRef]

55. Waghmare, A.G.; Salve, M.K.; LeBlanc, J.G.; Arya, S.S. Concentration and characterization of microalgae proteins from Chlorella pyrenoidosa. Bioresour. Bioprocess. 2016, 3. [CrossRef]

56. Davis, J.P.; Foegeding, E.A.; Hansen, F.K. Electrostatic effects on the yield stress of whey protein isolate foams. Colloids Surfaces B 2004, 34, 13-23. [CrossRef]

57. Rangsansarid, J.; Cheetangdee, N.; Kinoshita, N.; Fukuda, K. Bovine serum albumin-sugar conjugates through the Maillard reaction: Effects on interfacial behavior and emulsifying ability. J. Oleo Sci. 2008, 57, 539-547. [CrossRef]

58. Grossmann, L.; Ebert, S.; Hinrichs, J.; Weiss, J. Formation and Stability of Emulsions Prepared with a Water-Soluble Extract from the Microalga Chlorella protothecoides. J. Agric. Food Chem. 2019, 67, 6551-6558. [CrossRef]

59. Grønli, M.G.; Várhegyi, G.; Di Blasi, C. Thermogravimetric analysis and devolatilization kinetics of wood. Ind. Eng. Chem. Res. 2002, 41, 4201-4208. [CrossRef]

60. Rommi, K.; Niemi, P.; Kemppainen, K.; Kruus, K. Impact of thermochemical pre-treatment and carbohydrate and protein hydrolyzing enzyme treatment on fractionation of protein and lignin from brewer's spent grain. J. Cereal Sci. 2018, 79, 168-173. [CrossRef]

61. Dinwoodie, J.M. Wood: Nature's cellular polymeric composite. Phys. Technol. 1978, 9, 185-191. [CrossRef]

62. Fan, Y.; Hornung, U.; Dahmen, N.; Kruse, A. Hydrothermal liquefaction of protein-containing biomass: Study of model compounds for Maillard reactions. Biomass Convers. Bior. 2018, 8, 909-923. [CrossRef]

63. Ricci, L.; Umiltà, E.; Righetti, M.C.; Messina, T.; Zurlini, C.; Montanari, A.; Bronco, S.; Bertoldo, M. On the thermal behavior of protein isolated from different legumes investigated by DSC and TGA. J. Sci. Food Agric. 2018, 98, 5368-5377. [CrossRef]

64. Mariotti, F.; Tomé, D.; Mirand, P.P. Converting nitrogen into protein - Beyond 6.25 and Jones' factors. Crit. Rev. Food Sci. Nutr. 2008, 48, 177-184. [CrossRef]

Sample Availability: Sample Availability: Not available.

(C) 2020 by the authors. Licensee MDPI, Basel, Switzerland. This article is an open access article distributed under the terms and conditions of the Creative Commons Attribution (CC BY) license (http://creativecommons.org/licenses/by/4.0/). 